Article

\title{
Aqueous Preparation of Platinum Nanoflowers on Three-Dimensional Graphene for Efficient Methanol Oxidation
}

\author{
Ying Zhang ${ }^{1}$, Zhouwei Shao ${ }^{1}$, Qi Shen ${ }^{1}$, Mengyang $\mathrm{Li}^{1}{ }^{1}, \mathrm{Lin} \mathrm{Xu}^{2, *}$ and Zhimin Luo ${ }^{1, *}$ \\ 1 Key Laboratory of Radio Frequency and Micro-Nano Electronics of Jiangsu Province, College of Electronic \\ and optical Engineering \& College of Microelectronic, Key Laboratory for Organic Electronics and \\ Information Displays \& Jiangsu Key Laboratory for Biosensors, Institute of Advanced Materials (IAM), \\ Jiangsu National Synergistic Innovation Center for Advanced Materials (SICAM), Nanjing University of \\ Posts and Telecommunications, 9 Wenyuan Road, Nanjing 210023, China; yingzhang@njupt.edu.cn (Y.Z.); \\ njuptiamszw@163.com (Z.S.); marcoshen_njupt@163.com (Q.S.); justan22@163.com (M.L.) \\ 2 Jiangsu Key Laboratory of New Power Batteries, Jiangsu Collaborative Innovation Center of Biomedical \\ Functional Materials, School of Chemistry and Materials Science, Nanjing Normal University, \\ Nanjing 210023, China \\ * Correspondence: njuxulin@gmail.com (L.X.); iamzmluo@njupt.edu.cn (Z.L.); \\ Tel.: +86-025-8586-6332 (L.X. \& Z.L.)
}

Received: 17 September 2018; Accepted: 31 October 2018; Published: 5 November 2018

\begin{abstract}
A facile aqueous method to construct a platinum nanoflowers (PtNFs)/three-dimensional (3D) graphene electrode for electrochemical catalysis was demonstrated. PtNFs composed of thin $\mathrm{Pt}$ nanowires with the length of 6-16 $\mathrm{nm}$ and the diameter of 2-3 nm were prepared on 3D graphene foam as a growth template in the aqueous solution without any surfactant. The 3D graphene foam was used for patterning PtNFs and controlling their morphology. The fabricated PtNF/3D graphene electrode was applied for electrocatalytic methanol oxidation. Electrochemical measurements show that the PtNF/3D graphene electrode has higher electrocatalytic activity and better stability than commercial $\mathrm{Pt}-\mathrm{C}$ modified glassy carbon electrode. It displays promising potential for applications in fuel cells.
\end{abstract}

Keywords: three-dimensional graphene; platinum nanoflowers; aqueous synthesis; electrocatalysis; methanol oxidation

\section{Introduction}

Currently, platinum-based nanostructures have attracted much attention in the development of chemical sensors [1], biosensors [2,3], and electrocatalysts of fuel cells [4-9] because of their unusual physical and chemical characteristics. The properties of Pt-based nanostructures, especially electrocatalytic activity, exceedingly rely on their shape, size, crystallinity and composition [10-12]. Since platinum is scarce in nature, great effort has been made to improve its catalytic activity to reduce its use $[13,14]$. Two main strategies have been developed. One is focused on Pt-based nanostructures, such as synthesis of platinum nanocrystals with various dimensionality $[15,16]$, advanced nanocomposites based on Pt nanostructures [17,18], Pt-based alloy, and binary metals [8, 19-21]. The other is developing efficient support materials to enhance dispersion and catalytic efficiency of Pt nanostructures, such as carbon nanofibers [22,23], carbon nanotubes [24-26], carbon nanospheres [12], graphene oxide [11], graphene [27], etc.

Among these support materials, graphene, a kind of two-dimensional carbon nanomaterial with a honeycomb lattice, has attracted tremendous interest due to its high conductivity, superior 
mechanical properties, large thermal conductivity, and large surface area [27-29]. Its unique properties make it ideal for many new applications such as nanoelectronics [30], supercapacitors [31], ultrasensitive sensors [32,33], lithium batteries [34], catalysis in fuel cells [35,36], etc. Graphene supported Pt composites are meaningful for electrochemical catalysis. Until now, most of graphene/Pt composites are studied by incorporating Pt nanoparticles onto reduced graphene oxides or graphene oxides [11,19,37-39]. Those kinds of structures easily suffer from aggregation, which causes inferior ionic accessibility and limited improvement of electrocatalytic performance of Pt catalysts [40]. Three-dimensional (3D) graphene foam, a kind of interconnected graphene network, exhibits an open-pore honeycomb structure of graphene with high surface area, large void volume, strong corrosion resistance, and excellent conductivity $[27,40]$. These properties of $3 \mathrm{D}$ graphene foam make it ideal as an electrode material to support catalysts in fuel cells.

In our work, 3D graphene foam was used as a support for direct growth of platinum nanoflowers (PtNFs) under room temperature in aqueous solution without any surfactant. Monomorphic PtNFs composed of thin Pt nanowires were successfully synthesized through the template function of 3D graphene. The 3D graphene-supported PtNFs act as a novel 3D electrode for methanol oxidation reaction (MOR), which holds many advantages including improving the interaction between PtNFs and 3D graphene and enhancing mass transport in the process of electrocatalysis. The fabricated $\mathrm{PtNF} / 3 \mathrm{D}$ graphene electrode shows higher electrocatalytic activity and better CO tolerance for methanol oxidation than that of the commercial Pt-C catalyst (Hispec4000) modified glassy carbon electrode (GCE) (Pt-C/GCE).

\section{Results and Discussion}

Scanning electron microscopy (SEM) micrographs of 3D graphene foam in Figure 1 show that it has a well-defined macroporous structure with a thin and smooth graphene skeleton. Raman spectra taken from different regions of 3D graphene foam present a $G$ band at $\sim 1560 \mathrm{~cm}^{-1}$ and $2 \mathrm{D}$ band at $\sim 2700 \mathrm{~cm}^{-1}$ (Figure 2). The ratio of the intensity of the $\mathrm{G}$ band $\left(I_{G}\right)$ and $2 \mathrm{D}$ band $\left(I_{2 D}\right)$ is related to the number of layers of graphene [27]. The sharp and symmetric 2D band corresponds with a single-layer graphene, and the broad 2D band corresponds with a few-layer graphene in Figure 2, indicating that the prepared 3D graphene foam comprises both single-layer and few-layer graphene [41-46]. Furthermore, the absence of an obvious disorder-induced D band from the Raman characterization of 3D graphene foam suggests its high quality [45].
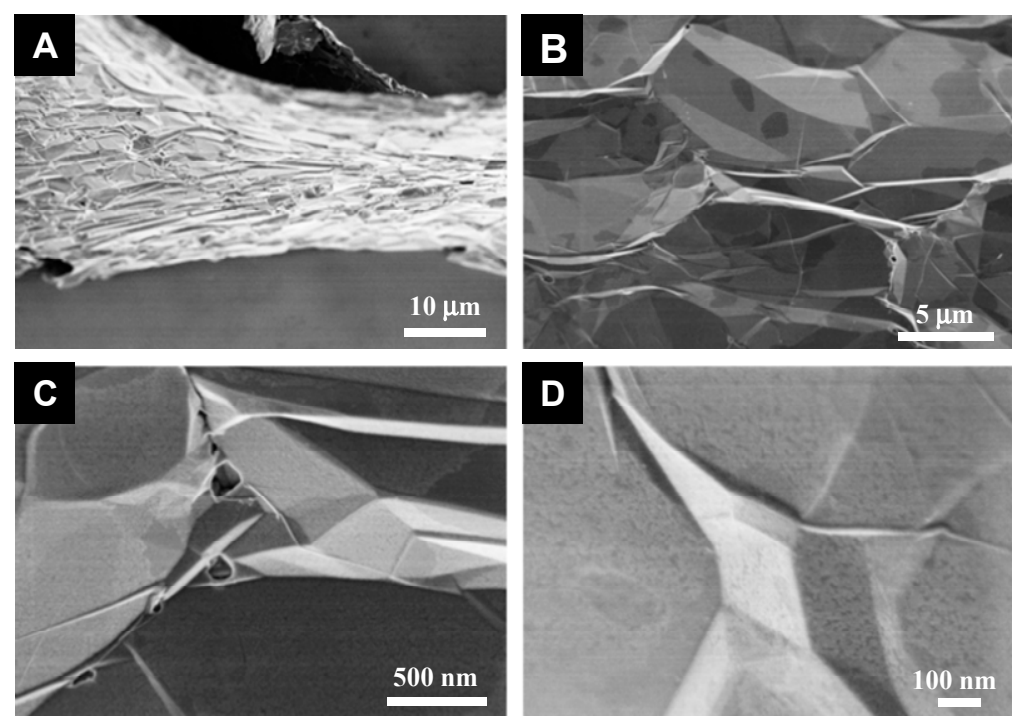

Figure 1. (A-D) SEM micrographs of three-dimensional (3D) graphene foam with different magnifications. 


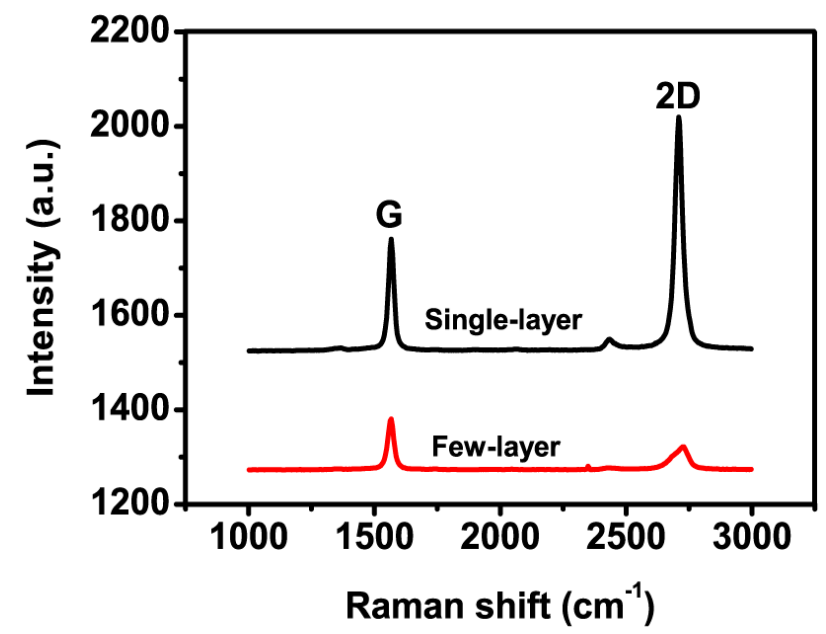

Figure 2. Raman spectra recorded at different regions of 3D graphene foam.

3D graphene foam was directly used as a growing template for synthesis of PtNFs. The experimental details can be seen in the Materials and Methods section. The morphology and structure of PtNFs growing on 3D graphene can be modulated by the addition of a Pt precursor. These were studied by SEM and transmission electron microscopy (TEM) characterizations. As shown in Figures $3 \mathrm{~A}$ and $4 \mathrm{~A}-\mathrm{C}, 3 \mathrm{D}$ PtNFs uniformly cover the surface of 3D graphene by a considerable amount. When the addition of $\mathrm{H}_{2} \mathrm{PtCl}_{6} \cdot 6 \mathrm{H}_{2} \mathrm{O}$ increases from 2.2 to $4.4 \mathrm{mg}$, the distribution and number of PtNFs per unit surface area of 3D graphene increases. The TEM images (Figure 3B,C) reveal that many $\mathrm{Pt}$ nanowires with the length of 6-16 nm are located together to form 3D flower-like nanostructures. High-resolution TEM (HRTEM) characterizations (Figures 3D and 4D) demonstrate that each PtNF consists of many Pt nanowires with the diameter of 2-3 nm, and the amount of Pt nanowires increases with the increase of Pt precursor. The magnified HRTEM image in Figure 4D shows that the nanowire grown on 3D graphene is one single crystal with the lattice spacing of $0.225 \mathrm{~nm}$, which is attributed to the (111) crystal plane of $\mathrm{Pt}[47,48]$. The energy-dispersive X-ray spectroscopy (EDS) characterization (Figure 5A) further confirms the formation of PtNFs on 3D graphene.
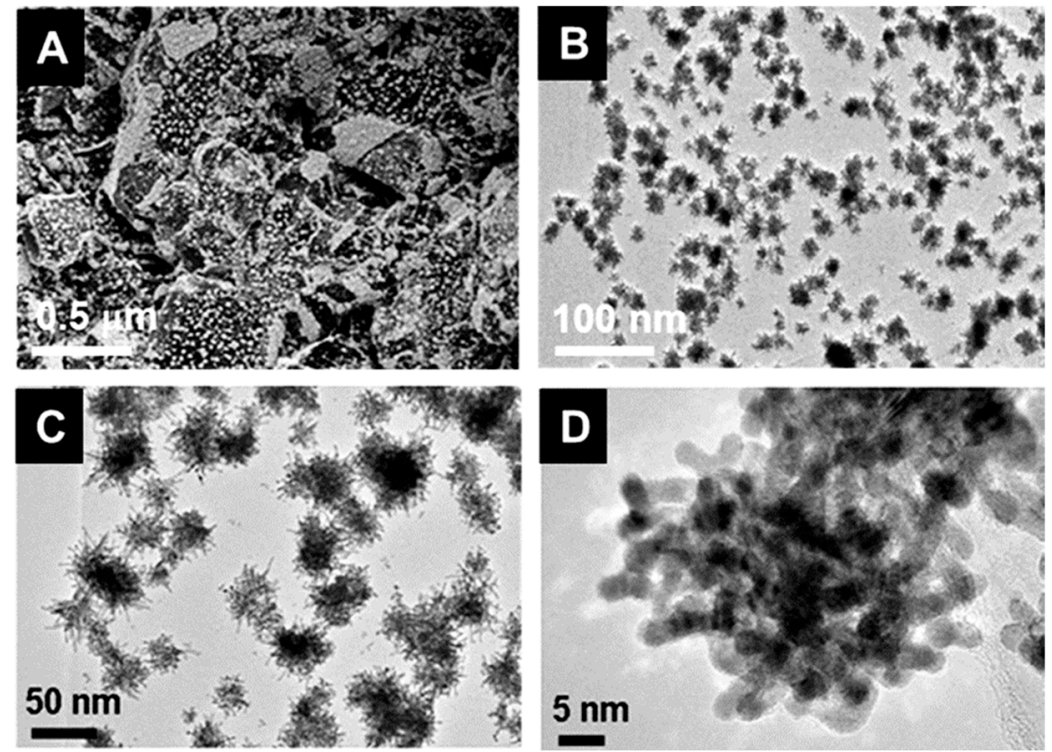

Figure 3. (A) SEM and (B) TEM micrographs of formed platinum nanoflower (PtNF)/3D graphene. (C) Magnified TEM micrograph of PtNF/3D graphene. (D) High-resolution TEM (HRTEM) micrograph of the prepared PtNF on 3D graphene. Preparation condition: $0.22 \mathrm{~mL}$ of $\mathrm{H}_{2} \mathrm{PtCl}_{6} \cdot 6 \mathrm{H}_{2} \mathrm{O}\left(10 \mathrm{mg} \mathrm{mL}^{-1}\right)$. 

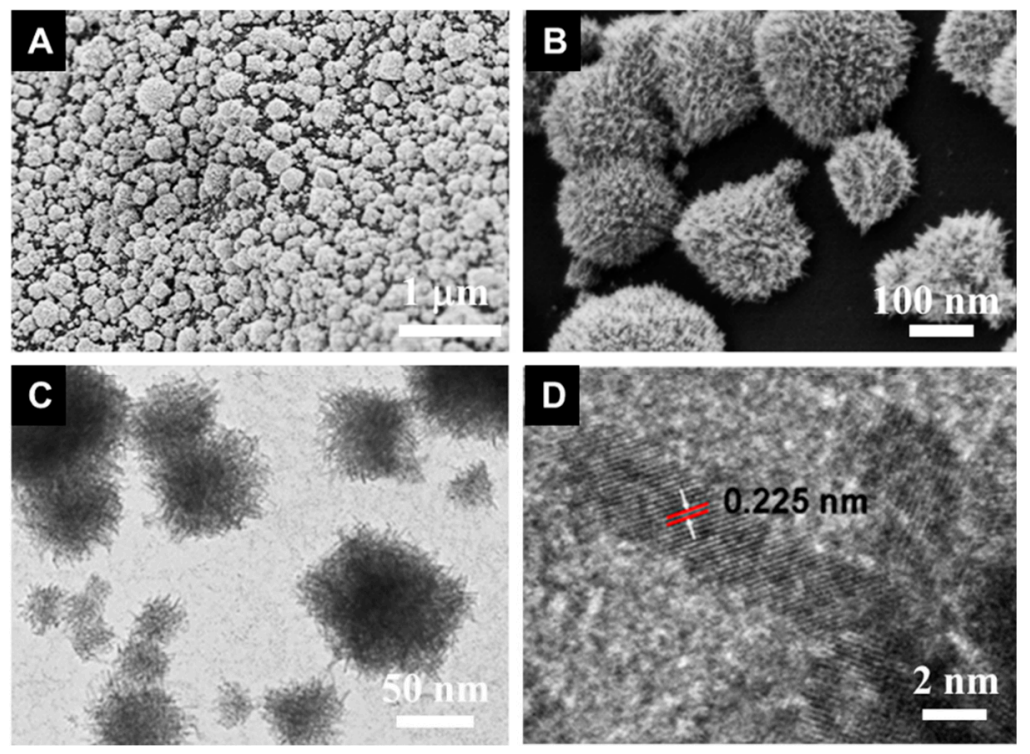

Figure 4. (A) SEM micrograph of formed PtNFs/3D graphene. (B) Magnified SEM micrograph of PtNFs on 3D graphene. (C) TEM micrograph of the prepared PtNFs on 3D graphene. (D) HRTEM micrograph of several Pt nanowires in the prepared PtNFs. Preparation condition: $0.44 \mathrm{~mL} \mathrm{of} \mathrm{H}_{2} \mathrm{PtCl}_{6} \cdot 6 \mathrm{H}_{2} \mathrm{O}$ $\left(10 \mathrm{mg} \mathrm{mL}^{-1}\right)$.

X-ray diffraction (XRD) spectra of 3D graphene foam and PtNF/3D graphene foam (Figure 5B) show a sharp peak of (002) reflection at $26.4^{\circ}$ (d-spacing $3.40 \AA$ ), which is close to the (002) reflection of graphite at $2 \theta=26.6^{\circ}(\mathrm{d}$-spacing $3.35 \AA \hat{)}$ ), indicating that graphene layers are regularly stacked $[49,50]$. A small diffraction peak at $2 \theta=54.5^{\circ}$ in Figure $5 \mathrm{~B}(\mathrm{a})$ is attributed to the (004) reflection of graphitic carbon [42]. Strong diffraction peaks at $2 \theta=39.8^{\circ}, 46.3^{\circ}, 67.8^{\circ}$, and $81.5^{\circ}$ in Figure $5 \mathrm{~B}(\mathrm{~b})$ can be assigned to (111), (200), (220), and (311) diffraction of face-centered-cube Pt (Joint Committee on Powder Diffraction Standards: 87-0647), respectively.
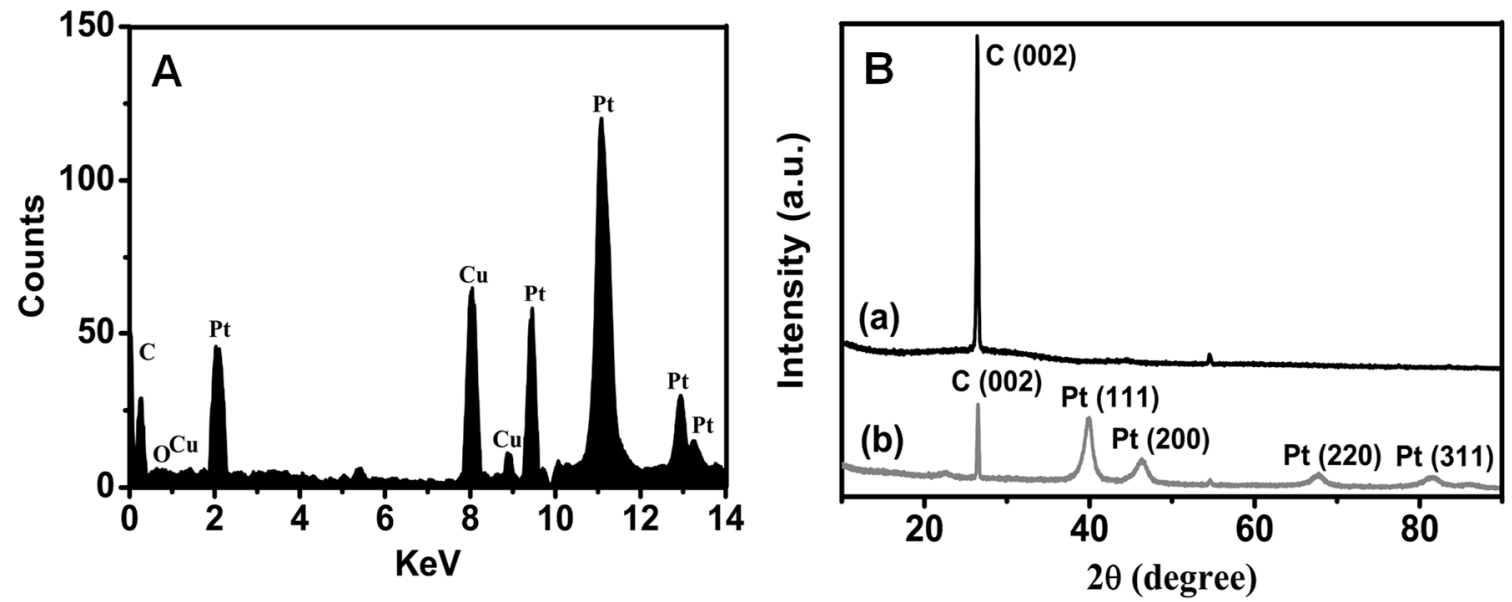

Figure 5. (A) Energy-dispersive X-ray spectroscopy (EDS) characterization of PtNFs grown on 3D graphene. (B) XRD characterizations of (a) 3D graphene foam and (b) PtNF/3D graphene electrode.

The fabricated PtNF/3D graphene electrode was used for electrocatalytic methanol oxidation against Pt-C/GCE. The TEM and XRD characterizations of used commercial Pt-C catalyst are presented in Figure S1. From the cyclic voltammograms (CVs) of Pt-C/GCE and PtNF/3D graphene electrodes in $\mathrm{N}_{2}$-saturated $0.5 \mathrm{M} \mathrm{H}_{2} \mathrm{SO}_{4}$ solution (Figure $6 \mathrm{~A}$ ), the $\mathrm{PtNF} / 3 \mathrm{D}$ graphene electrode shows stronger electrochemical peaks ascribed to hydrogen adsorption/desorption than that of Pt-C/GCE, indicating its larger electrochemically active surface area. The electrochemically active surface areas of Pt-C/GCE 
and PtNF/3D graphene were evaluated from their CVs to be $29.2 \mathrm{~cm}^{2} \mathrm{~g}^{-1}$ and $67.5 \mathrm{~cm}^{2} \mathrm{~g}^{-1}$, respectively. The MOR of Pt-C/GCE and $\mathrm{PtNF} / 3 \mathrm{D}$ graphene electrode in $\mathrm{N}_{2}$-saturated $0.5 \mathrm{M}$ $\mathrm{H}_{2} \mathrm{SO}_{4}$ solution is shown in Figure $6 \mathrm{~B}$. The PtNF/3D graphene electrode has higher electrocatalytic activity for MOR than Pt-C/GCE. The mass activity of PtNF/3D graphene electrode for MOR was $306.3 \mathrm{~mA} \mathrm{mg}^{-1} \mathrm{Pt}$ at $0.7 \mathrm{~V}$, which was 2.69 times higher than that of Pt-C/GCE $\left(113.8 \mathrm{~mA} \mathrm{mg}^{-1} \mathrm{Pt}\right)$ (Figure $6 \mathrm{C})$. The ratio of the forward oxidation peak intensity $\left(\mathrm{I}_{\mathrm{f}}\right)$ to the reverse peak intensity $\left(\mathrm{I}_{\mathrm{b}}\right)\left(\mathrm{I}_{\mathrm{f}} / \mathrm{I}_{\mathrm{b}}\right)$, is generally used to evaluate the $\mathrm{CO}$ and other carbonaceous species tolerance of catalysts. The value of $\mathrm{I}_{\mathrm{f}} / \mathrm{I}_{\mathrm{b}}$ of PtNF/3D graphene electrode $\left(\mathrm{I}_{\mathrm{f}} / \mathrm{I}_{\mathrm{b}}=1.3\right)$ is higher than that of Pt-C/GCE $\left(\mathrm{I}_{\mathrm{f}} / \mathrm{I}_{\mathrm{b}}=0.72\right)$ (Figure 6C), indicating that PtNF/3D graphene electrode can electrochemically oxidize methanol more effectively and generate less poisoning species than Pt-C/GCE during the forward scan. The durability of electrocatalysts is very significant for practical applications of catalysts. Chronoamperometric measurements of the PtNF/3D graphene electrode and Pt-C/GCE at $0.7 \mathrm{~V}$ for MOR show that the decay of peak current density of Pt-C/GCE for MOR is faster than that of the PtNF/3D graphene electrode (Figure 6D), suggesting that the PtNF/3D graphene electrode is more stable for MOR in acidic electrolytes. The high electrocatalytic activity and good stability of PtNF/3D graphene electrode are attributed to the high specific surface area of 3D graphene foam and exposed crystal plane (111) of thin $\mathrm{Pt}$ wires in a PtNF /3D graphene electrode. Specific surface area of 3D graphene foam $\left(670 \mathrm{~m}^{2} \mathrm{~g}^{-1}\right)$ [51] is larger than that of carbon black of commercial Pt-C $\left(250 \mathrm{~m}^{2} \mathrm{~g}^{-1}\right)$ [52]. Furthermore, the crystal plane (111) was proved to have a low tendency to be poisoned by CO intermediates [53].

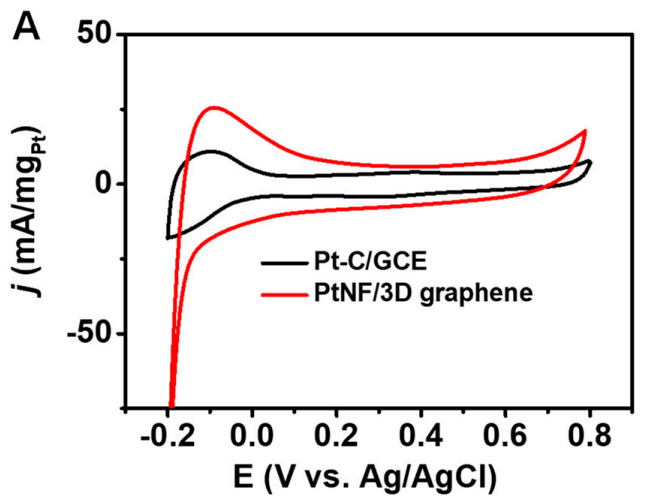

C

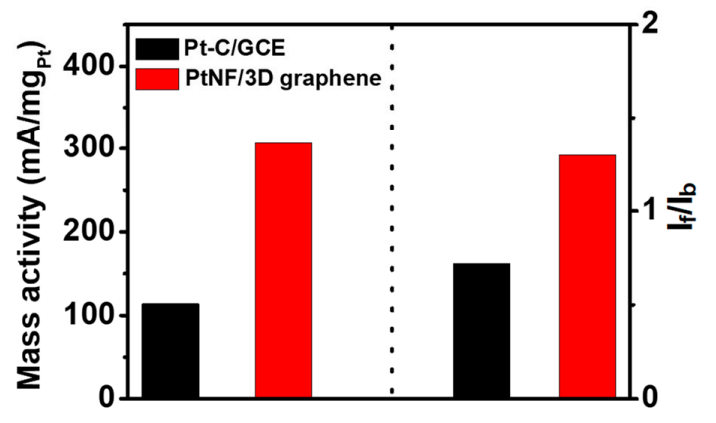

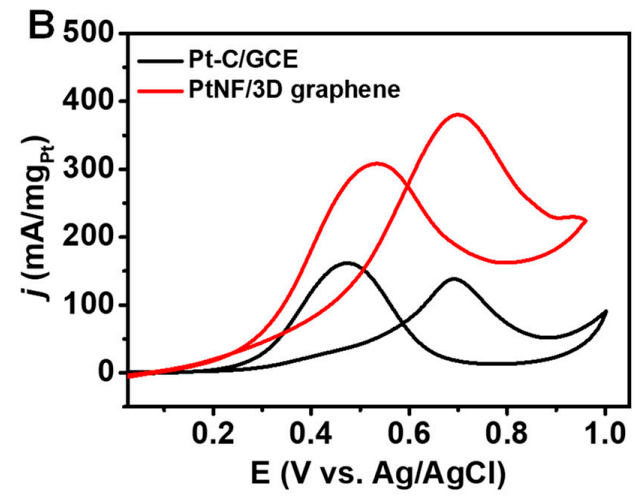

D

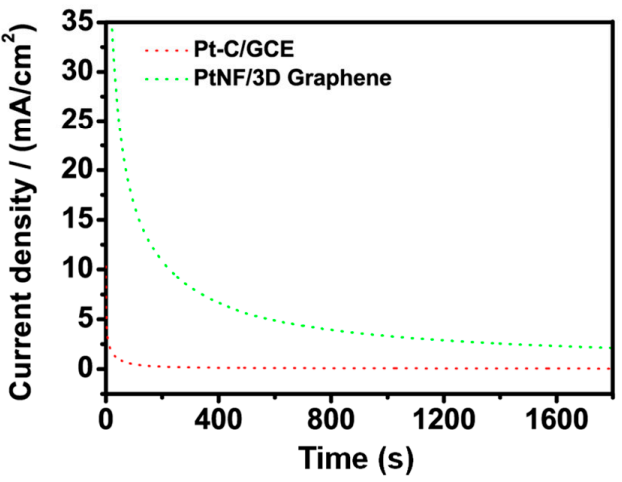

Figure 6. (A) Cyclic voltammogram (CV) measurements of Pt-C/glassy carbon electrode (GCE) and $\mathrm{PtNF} / 3 \mathrm{D}$ graphene electrode in $\mathrm{N}_{2}$-saturated $0.5 \mathrm{M} \mathrm{H}_{2} \mathrm{SO}_{4}$ solution. (B) $\mathrm{CV}$ measurements of $\mathrm{Pt}-\mathrm{C} / \mathrm{GCE}$ and PtNF/3D graphene electrode in $\mathrm{N}_{2}$-saturated $0.5 \mathrm{M} \mathrm{H}_{2} \mathrm{SO}_{4}$ solution containing $1.0 \mathrm{M}$ $\mathrm{CH}_{3} \mathrm{OH}$. (C) Mass activity at $0.7 \mathrm{~V}$ and $\mathrm{I}_{\mathrm{f}} / \mathrm{I}_{\mathrm{b}}$ of Pt-C/GCE and PtNF/3D graphene for methanol oxidation reaction (MOR). (D) Amperometric curves of Pt-C/GCE and PtNF/3D graphene at $0.7 \mathrm{~V}$ in $\mathrm{N}_{2}$-saturated $0.5 \mathrm{M} \mathrm{H}_{2} \mathrm{SO}_{4}$ solution containing $1.0 \mathrm{M} \mathrm{CH}_{3} \mathrm{OH}$. Scan rate in $\mathrm{CV}$ measurements of Figure $6 \mathrm{~A}, \mathrm{~B}$ is $50 \mathrm{mV} \mathrm{s}^{-1}$. Current density in Figure $6 \mathrm{D}$ was normalized with the geometric surface area of electrodes. 


\section{Materials and Methods}

\subsection{Materials}

Ethanol (absolute, $\geq 99.9 \%$ ), chloroplatinic acid hexahydrate $\left(\mathrm{H}_{2} \mathrm{PtCl}_{6} \cdot 6 \mathrm{H}_{2} \mathrm{O}\right)$ (analytical reagent, $\mathrm{Pt} \geq 37.5 \%$ ), formic acid (analytical reagent, 99\%), and methanol (absolute, $\geq 99.9 \%$ ) were purchased from Sigma-Aldrich (St. Louis, MO, USA). The commercial Pt/C (40 wt \% loading on carbon black, Hispec4000) was purchased from Shanghai Hesen Electric Co., Ltd. (Shanghai, China).

\subsection{Preparation of PtNF/3D Graphene Electrode}

3D graphene foams were prepared by chemical vapor deposition using ethanol as the precursor and nickel foam as a template according to the previously reported method [41,42]. The synthesized 3D graphene foams were used for growth of PtNFs through chemical reduction of chloroplatinic acid hexahydrate with formic acid. In a typical procedure, $0.40 \mathrm{~mL}$ formic acid and $0.44 \mathrm{~mL}$ chloroplatinic acid hexahydrate $\left(10 \mathrm{mg} \mathrm{mL}^{-1}\right)$ were added into a $10-\mathrm{mL}$ flask and sonicated for $30 \mathrm{~min}$. 3D graphene foam was immersed into the mixed solution, and then the reaction proceeded in an airtight flask at room temperature for up to $4 \mathrm{~d}$ without stirring. The 3D graphene foam loaded with PtNFs was pulled out and washed with deionized water many times, and then was dried at $60{ }^{\circ} \mathrm{C}$ in a vacuum drying oven. Since the reaction time of $4 \mathrm{~d}$ is enough to finish the reaction, the amount of PtNFs on 3D graphene in our work could be modulated by the addition of chloroplatinic acid hexahydrate.

\subsection{Characterizations}

SEM images of samples were obtained by scanning electron microscope (JEOL, Akishima, Japan, 7600F). TEM and HRTEM images of PtNF/3D graphene were recorded on a transmission electron microscope (200 kV, JEOL JEM-2100F) operated at $200 \mathrm{kV}$. Element analyses of PtNF/3D graphene was measured with an EDS. XRD characterizations were carried out with an X-ray diffractometer (Shimadzu, Kyoto, Japan, XRD-6000). Raman spectra of 3D graphene foam were recorded by a Raman micro-spectrometer (Renishaw, Wharton Anderch, UK).

\subsection{Electrochemical Measurements}

Pt loading on PtNF/3D graphene was estimated by inductive coupled plasma-optical emission spectroscopy (ICP-OES). Pt loading per unit geometric surface area of PtNF/3D graphene electrode and Pt-C/GCE $\left(0.158 \mathrm{mg} / \mathrm{cm}^{2}\right)$ was kept the same for electrochemical tests. Electrochemical experiments were implemented by using $\mathrm{Ag} / \mathrm{AgCl}(3 \mathrm{M} \mathrm{KCl})$ as a reference electrode, $\mathrm{Pt}$ wire as a counter electrode, and PtNF/3D graphene or Pt-C/GCE as a work electrode. The work electrode was firstly activated by CVs from -0.2 to $0.8 \mathrm{~V}$ in $\mathrm{N}_{2}$-saturated $0.5 \mathrm{M} \mathrm{H}_{2} \mathrm{SO}_{4}$ solution until $\mathrm{CV}$ becomes steady. MOR was measured by $\mathrm{CVs}$ from 0 to $1.0 \mathrm{~V}$ in $0.5 \mathrm{M} \mathrm{H}_{2} \mathrm{SO}_{4}$ solution containing $1.0 \mathrm{M} \mathrm{CH}_{3} \mathrm{OH}$. The scan rate for CVs was $50 \mathrm{mV} \mathrm{s}^{-1}$.

\section{Conclusions}

In summary, a PtNF/3D graphene electrode was constructed by a simple aqueous method with 3D graphene foam as the growth template of PtNFs. PtNFs were easily and controllably formed on the 3D graphene foam under room temperature without any assistance of surfactants. The fabricated PtNF/3D graphene electrode shows high electrocatalytic activity and good stability for MOR. This easy method is meaningful for designing and preparing highly efficient 3D inorganic nanostructures/graphene electrodes in the applications of fuel cells.

Supplementary Materials: The following are available online at http:/ / www.mdpi.com/2073-4344/8/11/519/s1, Figure S1: Figure S1. (A) TEM and (B) XRD characterizations of the used commercial Pt-C catalyst.

Author Contributions: Y.Z., L.X. and Z.L. proposed the concept and supervised the research work. Z.S., Q.S. and M.L. designed and performed the experiments. All authors analyzed the data and wrote the paper. 
Funding: This research was funded by the National Key Research and Development Program of China (2017YFA0205302), the National Natural Science Foundation of China (21475064, 61705113), the Program for Changjiang Scholars and Innovative Research Team in University (IRT_15R37), the Key Research and Development Program of Jiangsu (BE2018732), the Natural Science Key Fund for Colleges and Universities in Jiangsu Province (17KJA430011), and the University Science Research Project of Jiangsu Province (NY217007, NY218150).

Conflicts of Interest: The authors declare no conflict of interest.

\section{References}

1. Hutton, L.; Newton, M.E.; Unwin, P.R.; Macpherson, J.V. Amperometric oxygen sensor based on a platinum nanoparticle-modified polycrystalline boron doped diamond disk electrode. Anal. Chem. 2008, 81, 1023-1032. [CrossRef] [PubMed]

2. Yang, M.; Yang, Y.; Yang, H.; Shen, G.; Yu, R. Layer-by-layer self-assembled multilayer films of carbon nanotubes and platinum nanoparticles with polyelectrolyte for the fabrication of biosensors. Biomaterials 2006, 27, 246-255. [CrossRef] [PubMed]

3. Yang, M.; Yang, Y.; Liu, Y.; Shen, G.; Yu, R. Platinum nanoparticles-doped sol-gel/carbon nanotubes composite electrochemical sensors and biosensors. Biosens. Bioelectron. 2006, 21, 1125-1131. [CrossRef] [PubMed]

4. Ding, J.; Chan, K.Y.; Ren, J.; Xiao, F. Platinum and platinum-ruthenium nanoparticles supported on ordered mesoporous carbon and their electrocatalytic performance for fuel cell reactions. Electrochim. Acta 2005, 50, 3131-3141. [CrossRef]

5. Rolison, D.R. Catalytic nanoarchitectures-The importance of nothing and the unimportance of periodicity. Science 2003, 299, 1698-1701. [CrossRef] [PubMed]

6. Yasuda, K.; Taniguchi, A.; Akita, T.; Ioroi, T.; Siroma, Z. Platinum dissolution and deposition in the polymer electrolyte membrane of a PEM fuel cell as studied by potential cycling. Phys. Chem. Chem. Phys. 2006, 8, 746-752. [CrossRef] [PubMed]

7. Cao, X.; Han, Y.; Gao, C.; Xu, Y.; Huang, X.; Willander, M.; Wang, N. Highly catalytic active PtNiCu nanochains for hydrogen evolution reaction. Nano Energy 2014, 9, 301-308. [CrossRef]

8. Yan, X.; Yu, S.; Tang, Y.; Sun, D.; Xu, L.; Xue, C. Triangular AgAu@Pt core-shell nanoframes with a dendritic Pt shell and enhanced electrocatalytic performance toward the methanol oxidation reaction. Nanoscale 2017, 5, 2231-2235. [CrossRef] [PubMed]

9. Hsieh, Y.C.; Zhang, Y.; Su, D.; Volkov, V.; Si, R.; Wu, L.; Zhu, Y.; An, W.; Liu, P.; He, P.; et al. Ordered bilayer ruthenium-platinum core-shell nanoparticles as carbon monoxide-tolerant fuel cell catalysts. Nat. Commun. 2013, 4, 2466. [CrossRef] [PubMed]

10. Song, P.; Cui, X.; Shao, Q.; Feng, Y.; Zhu, X.; Huang, X. Networked Pt-Sn nanowires as efficient catalysts toward alcohol electrooxidation. J. Mater. Chem. A 2017, 5, 24626-24630. [CrossRef]

11. Chen, X.; Su, B.; Wu, G.; Yang, C.J.; Zhuang, Z.; Wang, X. Platinum nanoflowers supported on graphene oxide nanosheets: Their green synthesis, growth mechanism, and advanced electrocatalytic properties for methanol oxidation. J. Mater. Chem. 2012, 22, 11284-11289. [CrossRef]

12. Sun, S.; Jaouen, F.; Dodelet, J.P. Controlled growth of Pt nanowires on carbon nanospheres and their enhanced performance as electrocatalysts in PEM fuel cells. Adv. Mater. 2008, 20, 3900-3904. [CrossRef]

13. Bing, Y.; Liu, H.; Zhang, L.; Ghosh, D.; Zhang, J. Nanostructured Pt-alloy electrocatalysts for PEM fuel cell oxygen reduction reaction. Chem. Soc. Rev. 2010, 39, 2184-2202. [CrossRef] [PubMed]

14. Debe, M.K. Electrocatalyst approaches and challenges for automotive fuel cells. Nature 2012, 486, 43-51. [CrossRef] [PubMed]

15. Liang, H.W.; Cao, X.; Zhou, F.; Cui, C.H.; Zhang, W.J.; Yu, S.H. A free-standing Pt-nanowire membrane as a highly stable electrocatalyst for the oxygen reduction reaction. Adv. Mater. 2011, 23, 1467-1471. [CrossRef] [PubMed]

16. Sakai, N.; Tatsuma, T. One-step synthesis of glutathione-protected metal ( $\mathrm{Au}, \mathrm{Ag}, \mathrm{Cu}, \mathrm{Pd}$, and $\mathrm{Pt})$ cluster powders. J. Mater. Chem. A 2013, 1, 5915-5922. [CrossRef]

17. Cao, L.; Scheiba, F.; Roth, C.; Schweiger, F.; Cremers, C.; Stimming, U.; Fuess, H.; Chen, L.; Zhu, W.; Qiu, X. Novel nanocomposite $\mathrm{Pt} / \mathrm{RuO}_{2} \cdot \mathrm{xH}_{2} \mathrm{O} /$ carbon nanotube catalysts for direct methanol fuel cells. Angew. Chem. Int. Ed. 2006, 45, 5315-5319. [CrossRef] [PubMed] 
18. Zhang, S.; Shao, Y.; Yin, G.; Lin, Y. Electrostatic self-assembly of a Pt-around-Au nanocomposite with high activity towards formic acid oxidation. Angew. Chem. Int. Ed. 2010, 49, 2211-2214. [CrossRef] [PubMed]

19. Guo, S.; Dong, S.; Wang, E. Three-dimensional Pt-on-Pd bimetallic nanodendrites supported on graphene nanosheet: Facile synthesis and used as an advanced nanoelectrocatalyst for methanol oxidation. ACS Nano 2009, 4, 547-555. [CrossRef] [PubMed]

20. Wang, L.; Nemoto, Y.; Yamauchi, Y. Direct synthesis of spatially-controlled Pt-on-Pd bimetallic nanodendrites with superior electrocatalytic activity. J. Am. Chem. Soc. 2011, 133, 9674-9677. [CrossRef] [PubMed]

21. Liu, L.; Pippel, E.; Scholz, R.; Gösele, U. Nanoporous Pt-Co alloy nanowires: Fabrication, characterization, and electrocatalytic properties. Nano Lett. 2009, 9, 4352-4358. [CrossRef] [PubMed]

22. Steigerwalt, E.S.; Deluga, G.A.; Cliffel, D.E.; Lukehart, C. A Pt-Ru/graphitic carbon nanofiber nanocomposite exhibiting high relative performance as a direct-methanol fuel cell anode catalyst. J. Phys. Chem. B 2001, 105, 8097-8101. [CrossRef]

23. Zheng, J.S.; Wang, M.X.; Zhang, X.S.; Wu, Y.X.; Li, P.; Zhou, X.G.; Yuan, W.K. Platinum/carbon nanofiber nanocomposite synthesized by electrophoretic deposition as electrocatalyst for oxygen reduction. J. Power Sources 2008, 175, 211-216. [CrossRef]

24. Matsumoto, T.; Komatsu, T.; Arai, K.; Yamazaki, T.; Kijima, M.; Shimizu, H.; Takasawa, Y.; Nakamura, J. Reduction of Pt usage in fuel cell electrocatalysts with carbon nanotube electrodes. Chem. Commun. 2004, 7, 840-841. [CrossRef] [PubMed]

25. Xue, B.; Chen, P.; Hong, Q.; Lin, J.; Tan, K.L. Growth of Pd, Pt, Ag and Au nanoparticles on carbon nanotubes. J. Mater. Chem. 2001, 11, 2378-2381. [CrossRef]

26. Wu, G.; Xu, B.Q. Carbon nanotube supported Pt electrodes for methanol oxidation: A comparison between multi-and single-walled carbon nanotubes. J. Power Sources 2007, 174, 148-158. [CrossRef]

27. Maiyalagan, T.; Dong, X.; Chen, P.; Wang, X. Electrodeposited Pt on three-dimensional interconnected graphene as a free-standing electrode for fuel cell application. J. Mater. Chem. 2012, 22, 5286-5290. [CrossRef]

28. Cao, X.; Shi, Y.; Shi, W.; Lu, G.; Huang, X.; Yan, Q.; Zhang, Q.; Zhang, H. Preparation of novel 3D graphene networks for supercapacitor applications. Small 2011, 7, 3163-3168. [CrossRef] [PubMed]

29. Hou, J.; Shao, Y.; Ellis, M.W.; Moore, R.B.; Yi, B. Graphene-based electrochemical energy conversion and storage: Fuel cells, supercapacitors and lithium ion batteries. Phys. Chem. Chem. Phys. 2011, 13, 15384-15402. [CrossRef] [PubMed]

30. Dong, X.; Shi, Y.; Huang, W.; Chen, P.; Li, L.J. Electrical detection of DNA hybridization with single-base specificity using transistors based on CVD-grown graphene sheets. Adv. Mater. 2010, 22, 1649-1653. [CrossRef] [PubMed]

31. Miller, J.R.; Outlaw, R.; Holloway, B. Graphene double-layer capacitor with ac line-filtering performance. Science 2010, 329, 1637-1639. [CrossRef] [PubMed]

32. Ang, P.K.; Chen, W.; Wee, A.T.S.; Loh, K.P. Solution-gated epitaxial graphene as pH sensor. J. Am. Chem. Soc. 2008, 130, 14392-14393. [CrossRef] [PubMed]

33. Dua, V.; Surwade, S.P.; Ammu, S.; Agnihotra, S.R.; Jain, S.; Roberts, K.E.; Sungjin, P.; Rodney, S.R.; Sanjeev, K.M. All-organic vapor sensor using inkjet-printed reduced graphene oxide. Angew. Chem. Int. Ed. 2010, 49, 2154-2157. [CrossRef] [PubMed]

34. Reddy, A.L.M.; Srivastava, A.; Gowda, S.R.; Gullapalli, H.; Dubey, M.; Ajayan, P.M. Synthesis of nitrogen-doped graphene films for lithium battery application. ACS Nano 2010, 4, 6337-6342. [CrossRef] [PubMed]

35. Kampouris, D.K.; Banks, C.E. Exploring the physicoelectrochemical properties of graphene. Chem. Commun. 2010, 46, 8986-8988. [CrossRef] [PubMed]

36. Sutter, P.W.; Flege, J.I.; Sutter, E.A. Epitaxial graphene on ruthenium. Nat. Mater. 2008, 7, 406-411. [CrossRef] [PubMed]

37. Guo, S.; Wen, D.; Zhai, Y.; Dong, S.; Wang, E. Platinum nanoparticle ensemble-on-graphene hybrid nanosheet: One-pot, rapid synthesis, and used as new electrode material for electrochemical sensing. ACS Nano 2010, 4, 3959-3968. [CrossRef] [PubMed]

38. Si, Y.; Samulski, E.T. Exfoliated graphene separated by platinum nanoparticles. Chem. Mater. 2008, 20, 6792-6797. [CrossRef] 
39. Yao, Z.; Zhu, M.; Jiang, F.; Du, Y.; Wang, C.; Yang, P. Highly efficient electrocatalytic performance based on Pt nanoflowers modified reduced graphene oxide/carbon cloth electrode. J. Mater. Chem. 2012, 22, 13707-13713. [CrossRef]

40. Choi, B.G.; Yang, M.; Hong, W.H.; Choi, J.W.; Huh, Y.S. 3D macroporous graphene frameworks for supercapacitors with high energy and power densities. ACS Nano 2012, 6, 4020-4028. [CrossRef] [PubMed]

41. Chen, Z.; Ren, W.; Gao, L.; Liu, B.; Pei, S.; Cheng, H.M. Three-dimensional flexible and conductive interconnected graphene networks grown by chemical vapour deposition. Nat. Mater. 2011, 10, 424-428. [CrossRef] [PubMed]

42. Dong, X.C.; Xu, H.; Wang, X.W.; Huang, Y.X.; Chan-Park, M.B.; Zhang, H.; Wang, L.; Huang, W.; Chen, P. 3D graphene-cobalt oxide electrode for high-performance supercapacitor and enzymeless glucose detection. ACS Nano 2012, 6, 3206-3213. [CrossRef] [PubMed]

43. Ferrari, A.; Meyer, J.; Scardaci, V.; Casiraghi, C.; Lazzeri, M.; Mauri, F.; Piscanec, S.; Jiang, D.; Novoselov, K.S.; Roth, S.; et al. Raman spectrum of graphene and graphene layers. Phys. Rev. Lett. 2006, 97, 187401. [CrossRef] [PubMed]

44. Ni, Z.; Wang, H.; Kasim, J.; Fan, H.; Yu, T.; Wu, Y.; Feng, Y.P.; Shen, Z.X. Graphene thickness determination using reflection and contrast spectroscopy. Nano Lett. 2007, 7, 2758-2763. [CrossRef] [PubMed]

45. Ni, Z.H.; Yu, T.; Luo, Z.Q.; Wang, Y.Y.; Liu, L.; Wong, C.P.; Miao, J.; Huang, W.; Shen, Z.X. Probing charged impurities in suspended graphene using Raman spectroscopy. ACS Nano 2009, 3, 569-574. [CrossRef] [PubMed]

46. Graf, D.; Molitor, F.; Ensslin, K.; Stampfer, C.; Jungen, A.; Hierold, C.; Wirtz, L. Spatially resolved Raman spectroscopy of single-and few-layer graphene. Nano Lett. 2007, 7, 238-242. [CrossRef] [PubMed]

47. Su, L.; Jia, W.; Zhang, L.; Beacham, C.; Zhang, H.; Lei, Y. Facile synthesis of a platinum nanoflower monolayer on a single-walled carbon nanotube membrane and its application in glucose detection. J. Phys. Chem. C 2010, 114, 18121-18125. [CrossRef]

48. Sun, S.; Yang, D.; Villers, D.; Zhang, G.; Sacher, E.; Dodelet, J.P. Template-and surfactant-free room temperature synthesis of self-assembled 3D Pt nanoflowers from single-crystal nanowires. Adv. Mater. 2008, 20, 571-574. [CrossRef]

49. Ci, L.; Wei, B.; Xu, C.; Liang, J.; Wu, D.; Xie, S.; Zhou, W.; Li, Y.; Liu, Z.; Tang, D. Crystallization behavior of the amorphous carbon nanotubes prepared by the CVD method. J. Cryst. Growth 2001, 233, 823-828. [CrossRef]

50. Zhang, J.; Yang, H.; Shen, G.; Cheng, P.; Guo, S. Reduction of graphene oxide vial-ascorbic acid. Chem. Commun. 2010, 46, 1112-1114. [CrossRef] [PubMed]

51. Dong, X.; Wang, X.; Wang, L.; Song, H.; Zhang, H.; Huang, W.; Chen, P. 3D graphene foam as a monolithic and macroporous carbon electrode for electrochemical sensing. ACS Appl. Mater. Interfaces 2012, 4, 3129-3133. [CrossRef] [PubMed]

52. Niu, J.; Wang, J. Activated carbon nanotubes-supported catalyst in fuel cells. Electrochim. Acta 2008, 53, 8058-8063. [CrossRef]

53. Xia, X.H.; Iwasita, T.; Ge, F.; Vielstich, W. Structural effects and reactivity in methanol oxidation on polycrystalline and single crystal platinum. Electrochim. Acta 1996, 41, 711-718. [CrossRef]

(C) 2018 by the authors. Licensee MDPI, Basel, Switzerland. This article is an open access article distributed under the terms and conditions of the Creative Commons Attribution (CC BY) license (http://creativecommons.org/licenses/by/4.0/). 